\title{
A shared susceptibility locus in p53 for both gastric cancer and esophageal cancer in a northwestern Chinese population
}

\section{Juan Cao}

Ningxia Medical University

\section{Zhiqiang Chen}

General Hospital of Ningxia Medical University

Jing Chen

Ningxia Medical University

\section{Yanjie You}

People's Hospital of Ningxia Hui Autonomous Region

Chaoyong Tian

Xijing Hospital

Jia Yu

Ningxia Medical University

Hongfei Zhang

Ningxia Medical University

Jingwen Yang

Ningxia Medical University

Wenjun Yang ( $\square$ yw001@nxmu.edu.cn )

Northeast Normal University Institute of Polyoxometalate Chemistry

Research article

Keywords: rs1042522, GC, EC, SNPs

Posted Date: July 16th, 2019

DOI: https://doi.org/10.21203/rs.2.11462/v1

License: (c) (i) This work is licensed under a Creative Commons Attribution 4.0 International License. Read Full License 


\section{Abstract}

Background Upper gastrointestinal cancers are the leading causes of cancer-related deaths in Northwest China and share many similarities in terms of histological type, risk factors and genetic variants. We hypothesized that shared common genetic SNPs among eight SNPs in the p53 pathway existed among Ningxia gastric cancer (GC) and esophageal cancer (EC) patients. Methods A total of $180 \mathrm{GC}$ cases, 113 EC cases and 358 cancer-free control subjects from a high-incidence area for upper gastrointestinal cancers in Ningxia, China, were enrolled in this study. The genotyping of 8 SNPs was performed using PCR direct sequencing. P53 expression in GC and EC tissues was examined using the S-P immunohistochemical method. Multiple logistic regression analyses were used to estimate the association between genotypes and GC or EC risks. Kaplan-Meier and multivariate Cox regression analyses were carried out to evaluate the associations between genetic variants and overall survival. Result rs 1042522 was a common genetic locus shared by both Ningxia GC and EC patients. Compared with the rs1042522 Pro allele, the rs1042522 Arg allele increased the GC risk by 1.810 times and the EC risk by 2.285 times. Additionally, patients who carried the rs $1042522 \mathrm{Arg}$ allele and who also smoked or consumed alcohol had an increased risk for GC and EC. Cox survival analysis showed that neither p53 nor rs1042522 had an effect on the prognosis of GC and EC patients. Conclusion rs1042522 was a common genetic locus responsible for susceptibility shared by both northwestern GC and EC Chinese patients. Tobacco smoking and alcohol drinking further enhanced the cancer risk in our study.

\section{Background}

Gastric cancer (GC) and esophageal cancer (EC) are two deadly malignancies worldwide. Both GC and EC have been prevalent in China for decades with approximately fifty percent of the world's GC-related or ECrelated morbidity and mortality[1]. In 2018, GC was the fourth most frequently diagnosed cancer with nearly 456,124 new cases in China and the second leading cause of cancer-related deaths with 275,094 deaths. Similarly, EC ranked the sixth among the most common cancers with 307,359 new cases and the fourth in mortality leading to 283,433 deaths in China in 2018. However, both GC and EC have geographical variations in China. The Ningxia region, located in Northwest China, has had high incidence of GC and EC for decades, ranking first and sixth among all cancers in this region, respectively[2,3].

Due to the lack of highly effective biomarkers for early diagnosis and prognosis prediction, advanced stages of GC and EC are commonly present at the time of initial diagnosis. The age-standardized 5-year relative survival rates were only $27.4 \%$ and $21 \%$ in Chinese GC and EC patients, respectively[4]. Although many research works have been undertaken to elucidate the genetic factors for the etiology of GC and EC, the established genes or loci could only explain only a small part of cancer risk. In the remaining large portion of GC and EC patients, there has been a limited success in determining the genetic architecture of GC and EC. Some recent studies have focused on the investigating about whether GC and EC share common genetic SNPs. For example, Yao et al.[5] explored whether known 21 genetic susceptibility loci for EC were also important in the development of GC. They finally demonstrated that three genetic variants at 10q23.33, 5q11.2, and 12q24.12 may be useful as biomarkers to identify individuals with high risk for 
both ESCC and GC. Li et al. and Abnet et al. [6,7] reported that rs2274223 in the phospholipase C epsilon 1 gene (PLCE1) and rs1434285 in the epidermal growth factor receptor (EGFR) signaling pathway, which could increase the risk of GC and EC, were shared polymorphisms for both GC and EC susceptibility.

The polymorphisms in the p53 pathway have been suggested to contribute to the development of upper gastrointestinal cancer[6, 7]. rs1042522 in the p53 gene, also called p53 codon 72, has been widely studied for its association with the development of cancers [9, 10]. The 2 nd base of p53 codon 72 has a G/C variation, resulting in the replacement of arginine (Arg) with proline (Pro) amino acids [9,10]. Some studies have supported that the rs1042522 Arg allele increases the cancer risk, including lung cancer, breast cancer, and GC[12-14]. Other investigations showed that the rs1042522 Pro allele enhanced the risk of lung cancer, GC, and EC[15-17]. Accordingly, how p53 codon 72 works in cancer susceptibility remains inconclusive. In addition, several studies investigated the relationship between the rs 1042522 and the prognosis of cancer patients and reported that rs 1042522 was an independent prognostic factor for cancers $[18,19]$. Hence, rs 1042522 may be an independent factor affecting the prognosis of upper gastrointestinal cancer.

$\mathrm{p} 21^{\text {Waf1/Cip } 1}$, the main downstream regulator of tumor suppressor $\mathrm{p} 53$, functions as a unique link from p53 to cell-cycle arrest and DNA repair $[20,21]$. Thus, mutations or polymorphisms in the p21 Waf1/Cip1 gene may result in alteration of $\mathrm{p} 21^{\text {Waf1/Cip } 1}$ expression and/or activity, thereby modulating susceptibility to cancer. Seven tagging SNPs, including rs4135234, rs3829963, rs3829964, rs762624, rs2395655, rs730506, and rs3176320 were identified as risk factors for EC in Henan Province, located in the EastCentral China. However, their distributions and the associations with cancers in other Chinese populations are still very limited.

Here, we hypothesized that Ningxia GC and EC patients shared common genetic SNPs among eight SNPs in the p53 pathway. To prove our hypothesis, we genotyped eight SNPs to evaluate their associations with both GC and EC. Their crossover effects with smoking or drinking status on cancers, as well as their roles in the prognostic survival among cancer patients were also analyzed in a hospital-based northwestern Chinese population.

\section{Materials And Methods}

\section{Subjects for the case-control study}

A total of $180 \mathrm{GC}$ cases and $113 \mathrm{EC}$ cases were enrolled in this study that were histopathologically confirmed between 2012 and 2013 in the General Hospital of Ningxia Medical University, Yinchuan, Ningxia Hui Autonomous Region, China. Demographic data, including the age at diagnosis, gender, alcohol drinking and cigarette smoking, were obtained from medical records. Subjects with previous cancer and previous chemotherapy or radiotherapy were excluded. 
The 358 cancer-free control subjects matching the cases for gender (1:1) and age ( \pm 5 years) were randomly selected from a pool of healthy volunteers who came to the general health check-up center at the General Hospital during the same period. The recruited subjects were confirmed to be free of contraindications regarding endoscopic and cytology examinations. Demographic and risk factor data were collected by brief interviews. The study was approved by the Ningxia Medical University Ethical Review Committee, and all the participants provided written informed consent before entry into this study according to the regulations.

\section{DNA preparation and genotyping.}

Genomic DNA was extracted from peripheral blood leukocytes of the participants by using a QIAamp DNA Mini Kit (Qiagen, Hilden, Germany) following the manufacturer's instructions. SNP genotyping was performed using an improved multiplex ligase detection reaction method (iMLDR, Genesky Bio-Tech Cod., Ltd., Shanghai, China). Eight SNPs, including rs1042522, rs2395655, rs3176320, rs3829963, rs3829964, rs4135234, rs730506 and rs762624, in p53 or CDKN1A were tested. The polymerase chain reaction (PCR) primer pairs used to amplify the eight SNPs were the same as previously described [22] and were designed by Oligo5.0 software.

PCR was performed in a $25 \mu \mathrm{l}$ reaction mixture containing $1.0 \mu \mathrm{l}$ of DNA, $1.0 \mu \mathrm{l}$ of each primer, $2.0 \mu \mathrm{l}$ of dNTP, $2.0 \mu \mathrm{l}$ of $\mathrm{MgCl}_{2}, 0.5$ units of Taq DNA polymerase (Promega, Madison, WI) and 10 of reaction buffer. The PCR conditions consisted of an initial melting step of $2 \mathrm{~min}$ at $94^{\circ} \mathrm{C}$, followed by 35 cycles of $40 \mathrm{~s}$ at $94^{\circ} \mathrm{C}, 40 \mathrm{~s}$ at $52-61^{\circ} \mathrm{C}$, and $50 \mathrm{~s}$ at $72^{\circ} \mathrm{C}$, and a final elongation step of $10 \mathrm{~min}$ at $72^{\circ} \mathrm{C}$.

The polymorphisms were identified by directly sequencing of the PCR products using an ABI 3700 DNA sequencer (PE Applied Biosystems) with the forward primers. The sequencing chromatograms were basecalled with Phred (version 0.990722), assembled with Phrap (version 0.990329), and scanned by PolyPhred (version3.5), and the results were viewed with Consed (version 9.0). Sequence variations were confirmed by two authors independently.

\section{Follow-up}

All patients were followed up to confirm their living status or loss of follow-up by telephone or text messages. The GC and EC patients' data were followed up to January 24, 2019. Patients with one-call failure were contacted at least three times afterwards. Patients who could not be contacted after three attempts or who had wrong numbers were regarded as lost visits. Death was considered an event. Those who were alive, lost to follow-up or died from other diseases at the closing date were considered censored data. The survival data were available for 103 of $180 \mathrm{GC}$ cases $(57.2 \%)$ and 85 of $113 \mathrm{EC}$ cases $(75.2 \%)$. Overall survival was calculated from the operation time to the date of death or the last follow-up.

\section{Immunohistochemical analysis}


For further immunohistochemical analysis, $103 \mathrm{GC}$ cases and $85 \mathrm{EC}$ cases were retrieved from the $180 \mathrm{GC}$ and $113 \mathrm{EC}$ surgical patients mentioned above. All the specimens had been routinely formalin-fixed, paraffin-embedded and serially sectioned at $4 \mu \mathrm{m}$ in thickness. p53 protein expression in GC and EC tissues was examined using the S-P immunohistochemical method. Briefly, after routine deparaffinization and hydration, slides were treated with $1 \%$ hydrogen dioxide and then heated in EDTA ( $\mathrm{pH} \mathrm{8.0)}$ for antigen retrieval. Following blocking in $10 \%$ goat serum blocking, tissue sections were then incubated with mouse anti-Human p53 protein (Biogenex, San Raman, CA) at $4^{\circ} \mathrm{C}$ overnight. After rinsing, sections were subsequently incubated with goat anti-mouse biotin-conjugated IgG for $15 \mathrm{~min}$ and then with streptavidinperoxidase conjugate for $15 \mathrm{~min}$. The signal was developed with diaminobenzidine, and slides were counterstained with $5 \%$ hematoxylin. The brown signals located in the nucleus represent positive staining for P53 protein. Sections without monoclonal antibody treatment were used as negative controls. The staining was scored on a scale from 0 to III as follows: 0 , less than $10 \%$ cells were stained; I, $10-25 \%$ cells were stained; II, $26-50 \%$ cells were stained; and III, $>50 \%$ cells were stained. Scores I-III were classified as positive, while score 0 was negative.

\section{Statistical analysis}

Descriptive statistical analysis and unconditional logistic regression were performed by using the Statistical Package for the Social Sciences 17.0 (SPSS. Inc. Chicago IL, USA, Microsoft) and Statistical Analysis System software (version 8.01; SAS Institute, Cary, NC). Multiple logistic regression analyses were used to estimate the association between genotypes and GC or EC risks. Odds ratios (ORs) were adjusted for demographic variables, including age, gender, drinking and smoking. Crossover analyses were used to investigate the association between rs 1042522 and GC or EC by cigarette smoking or alcohol drinking status.

Cumulative survival rates were calculated from the date of initial diagnosis of GC or EC to the date of death or last follow-up. The Kaplan-Meier estimator was used to plot the survival curves, and multivariate analysis was performed using a Cox regression. Statistical significance was set at $P<0.05$, and all statistical tests were two-sided.

\section{Results}

\section{Part1}

\section{Demographic data of the participants}

A total of 651 Han people, including 180 GC cases, 115 EC cases and 358 cancer-free controls, were recruited in this study. Demographic data, including age, gender, cigarette smoking and alcohol drinking, for the subjects recruited in this study are summarized in Additional file: Table S1. The percentages of males in GC (71.7\%) and EC ( $75.2 \%)$ in the case group were higher than those in the control group 
(57.0\%), which was the same in cigarette smoking and alcohol drinking, and there were significant differences. All of the indexes in the GC or EC group were higher than those in the control group $(P<0.01)$.

\section{Genotype and allele frequencies of the SNPs in the case-control study}

The genotype and allele frequencies in the case and control groups are shown in Additional file: Table S2. Single SNP analyses showed that both p53 rs1042522 in 17p13.1 and CDKN1A rs730506 in 6p2 were significantly associated with EC susceptibility. The rs1042522 Arg allele was associated with an increased risk of EC when compared with the control group ( $52.7 \%$ vs. $43.0 \%, P=0.011)$. The distributions of p53 rs 1042522 CC, GC, and GG allele estimates for EC patients were $22.1 \%, 49.6 \%$ and $27.4 \%$, respectively. There were no significant differences in the other six SNPs between the GC or EC and the control group. Genotyping for SNP rs730506 variation revealed genotype frequencies of 3.5\% (CC), 20.4\% (GC), and $75.2 \%(G G)$ in the EC group, and $0.6 \%(C C), 26.3 \%(G C)$, and $72.9 \%(G G)$ in the control group.

\section{Associations between SNPs and GC or EC}

A multiple logistic regression model was used to estimate the association between the genotypes and the risk of GC or EC. The results are listed in Table 1 and Table 2, the results were adjusted by age, gender, cigarette smoking and alcohol drinking.

Only one of the eight SNPs, rs1042522 in 17p13.1, was associated with both GC and EC risks. The GC risk of rs1042522 Arg homozygote carriers was 2.064 times that of rs1042522 Pro homozygotes (adjusted OR $=2.064,95 \% \mathrm{Cl}=1.159-3.675, P=0.014)$. The rs $1042522 \mathrm{Arg}$ allele was also a risk factor for $\mathrm{GC}$ (adjusted $\mathrm{OR}=1.810,95 \% \mathrm{Cl}=1.151-2.847, P=0.010)$. When compared to the rs1042522 Pro homozygote, the rs1042522 Arg allele was associated with higher susceptibility to EC, even after adjustment for multiple conventional EC risk factors (adjusted $\mathrm{OR}=2.988,95 \% \mathrm{Cl}=1.486-6.009, P=0.002$; adjusted $\mathrm{OR}=1.883$, $95 \% \mathrm{Cl}=1.052-3.370, P=0.033)$. The rs1042522 Arg allele was also associated with an increased risk of EC when compared with the rs1042522 Pro allele (adjusted $\mathrm{OR}=2.285,95 \% \mathrm{Cl}=1.309-3.989, P=0.004$ ). However, no association between the other seven SNPs and GC or EC risk was observed in this study.

\section{Crossover analysis by cigarette smoking or alcohol drinking status}

The results are illustrated in Table 3 and Table 4. The results indicated that there was a significantly increased risk of GC among participants with the rs1042522 Arg allele who were also cigarette smokers or alcohol drinkers when compared to those non-cigarette smokers or non-alcohol drinkers who carried the rs1042522 Pro homozygote (adjusted $\mathrm{OR}=2.422,95 \% \mathrm{Cl}=1.145-5.123, P<0.001$, and adjusted $\mathrm{OR}=$ $5.152,95 \% \mathrm{Cl}=2.038-13.024, P<0.001$, respectively).

When focusing on rs1042522 Arg allele carriers who were also cigarette smokers or alcohol drinkers, the risk of EC increased (adjusted OR $=5.310,95 \% \mathrm{Cl}=2.623-11.300, P<0.001$, and adjusted $\mathrm{OR}=8.395$, $95 \% \mathrm{Cl}=3.961-18.380, P<0.001$, respectively). 


\section{Correlation of the rs1042522 genotype with the P53 expression of GC or EC patients}

To further analyze the effects of the rs1042522 genotype on P53 expression in human tissues, we examined the expression of P53 protein in 103 cases of GC and 85 cases of EC (Additional file: Table S3). Representative examples of negative p53 staining and positive I and above are shown in Figure $1 \mathrm{~A}-\mathrm{H}$. The brownish signals represent positive staining and were found mainly in the nucleus of tumor cells and the parabasal layer of normal gastric or esophageal mucosa. There was no statistical correlation between P53 expression and rs1042522, as shown in Additional file: Table S4.

\section{Survival analysis and multivariate analysis of overall survival}

In this retrospective study, there were a total of 103 and 85 survival data available out of the $180 \mathrm{GC}$ cases (57.2\%) and 113 EC cases (75.2\%), respectively. The median follow-up time was 43.0 months, and the 5year overall survival rate in GC patients was $48.5 \%$. In the EC patients, the median follow-up time was 45.5 months, and the 5 -year overall survival rate was $30.6 \%$. There was no significant survival difference between the positive and negative p53 patients, as shown in Additional file: Table S5. The multivariate Cox regression showed that both p53 and rs 1042522 had no effect on GC and EC patients' prognosis, and smoking and $\mathrm{N}$ stage were associated with the prognosis in EC patients (Table 5, 6 and Figure 1I-L).

\section{Discussion}

In the present study, we focused on investigating eight SNPs, including rs1042522 in the p53 gene and seven polymorphisms of $\mathrm{p} 21^{\text {Waf1/Cip } 1}$ among Chinese Ningxia GC and EC patients and cancer-free controls.

First, it was showed that rs 1042522 was the only common genetic locus shared by both Chinese Ningxia GC and EC patients among eight SNPs. Compared with the rs1042522 Pro allele, the rs 1042522 Arg allele increased the GC risk by 1.810 times, and the EC risk by 2.285 times as well. A group of studies supported that rs1042522 Arg was a potential cancer genetic risk factor, such as in breast cancer in Turkish patients and cutaneous melanoma in Caucasians [22]. Cheng et al.[25] reported that the rs1042522 Arg allele increased the GC risk by 1.17-fold compared with the rs 1042522 Pro allele in a meta-analysis with 7,444 GC cases and 9,984 controls among Eastern Asians. Our previous study also found that the rs 1042522 Arg allele contributed to an elevated esophageal squamous cell carcinoma risk by 6.48 times among a northern Chinese population[26]. These two studies were consistent with our present study. The functional mechanism behind this may result from the changing functions of the two alleles of rs1042522 in different cell types. Pim et al.[26] used an inducible switch system for expressing both rs1042522 Arg and rs1042522 Pro to investigate how the 2 forms of rs1042522 brought about a cessation of cell growth. 
They found that within the primary Saos-2 cells, the rs 1042522 Arg allele increased the ability of p53 to locate to mitochondria, which induced apoptosis more efficiently than the rs 1042522 Pro allele. However, Schneider-Stock, et al.[28] reported that in squamous cell carcinomas of the head and neck, the rs 1042522 Arg allele was associated with insufficient or absent apoptosis, because it lacked the apoptosis-related protein activities, such as the co-expression of Fas and FasL or high expression of Bcl2 protein. Furthermore, Garima et al. [29] found that compared to the rs 1042522 Pro allele, the rs $1042522 \mathrm{Arg}$ allele led to reduced expression of the cell proliferation inhibitor p21 and increased angiogenesis-mediating VEGF expression, promoting carcinoma growth through increased cell proliferation and vascularity in tumors arising in patients. Therefore, these changes in rs1042522 may affect the function of the p53 protein, attenuate the loss or alteration of p53 binding capacity to the targets and may induce aberrant cell amplification accompanying cellular transformation, which leads to the occurrence of different cancers[29].

Some studies have also shown that rs1042522 Arg allele represents a significant risk factor in the development of human papillomavirus (HPV) associated cancers. Steven et al.[31]evaluated the role of rs1042522 polymorphism and HPV status on the initiation, progression, and development of cervical cancer. They found that there was a significantly higher odds of progression from squamous intraepithelial lesions (SIL) to cervical cancer with the rs1042522 Arg allele in HPV-positive white and East Asian individuals. Storey et al.[32] reported there was a marked overrepresentation of homozygous rs1042522 Arg when compared with heterozygous or homozygous rs1042522 Pro, making individuals homozygous for rs1042522 Arg 7 times more likely to develop HPV-associated cervical cancer than individuals having one or more rs 1042522 Pro alleles. This could be explained by the studies from Storey et al. and Thomas et al. [32,33], who showed that rs1042522 Arg was significantly more susceptible to the degradation induced by HPV E6 protein than rs1042522 Pro. Therefore, the rs1042522 Arg allele represents a significant risk factor in the development of HPV-associated cancers.

However, several other studies reported that the rs 1042522 Pro allele was associated with the risk of cancer. For instance, Venkat $\mathrm{R}$ et al.[34] reported that African Americans, but not Caucasians, with the rs1042522 Pro homozygote had significantly higher mortality and 2.15-fold colorectal adenocarcinoma risk than those with the rs1042522 Arg allele. A group of studies also reported that the rs1042522 Pro allele increased the susceptibility of GC or EC among Asian patients from South China and Mongolia[15, 35].

The reasons for the contradictory results may be that the inherent genetic variant was distributed unevenly among different ethnic populations or even different people within the same ethnic group. Shi et al. [36]observed that the frequency of rs1042522 Arg allele expression was associated with low average winter temperature and that populations living in different latitudinal regions have a strong selection of different alleles of rs 1042522, especially because the latitude-dependent distribution of the genotypes was observed in the same ethnic group. Additionally, different environmental exposures or inadequate sample sizes may also be attributable to the inconsistent results. 
$\mathrm{GC}$ and EC are multifactorial disorders. Some common risk factors for GC include tobacco smoking, alcohol consumption, foods preserved by salting, older age, male gender, race, family history, low physical activity, low fiber intake and radiation[37]. Several studies demonstrated that cigarette smoking and alcohol consumption were risk factors for $\mathrm{GC}$ and $\mathrm{EC}[38,39]$ and may also lead to death from other smoking-related complications. In the present study, the crossover analysis by cigarette smoking or alcohol drinking status indicated that rs1042522 Arg allele carriers together with cigarette smoking or alcohol drinking further increased GC and EC risk.

Second, we also estimated the association of P53 expression and rs1042522 with the prognosis of cancer patients. Although the differences were not statistically significant, the overall survival rates of both GC and EC patients with p53 positive expression were higher than those with p53 negative expression, which was consistent with Wang's and Li's[41,42] investigations among 2,013 renal cell carcinoma patients and $150 \mathrm{GC}$ patients, respectively. However, although some groups also reported that rs1042522 had an effect on cancer survival[34,43], we did not find any relationship between this SNP and survival of GC or EC, which was consistent with the results from Hedayatizadeh-Omran et al.[44].

\section{Conclusion}

In conclusion, we comprehensively analyzed the associations between eight SNPs and their association with both GC and EC patients from Ningxia, China and found that rs 1042522 was a common genetic locus shared by GC and EC patients. Additionally, tobacco smoking and alcohol drinking could further enhance the risk of cancer susceptibility in our study. However, some limitations need to be addressed. First, all of the participants were enrolled from a hospital, and the subjects may not be representative of all upper gastrointestinal patients in this region. Accordingly, selection bias cannot be completely excluded. Second, our sample size was admittedly limited, allowing us to draw only preliminary conclusions. Third, human HPV infection was not detected among our patients. Therefore, further investigations with HPV detection, larger sample sizes and multiple populations are warranted to uncover the genetic basis of GC and EC.

\section{List Of Abbreviations}

GC: Gastric cancer EC: Esophageal cancer HPV: Human papillomavirus

PLCE1: Phospholipase C epsilon 1 EGFR: Epidermal growth factor receptor

Arg: arginine Pro: proline ORs: Odds ratios

PCR: polymerase chain reaction SIL: Squamous intraepithelial lesions

\section{Declarations}




\section{Acknowledgments}

We thank Wiley for the linguistic assistance during the preparation of this manuscript.

The research was supported by the grants from National Natural Science Foundation of China (No. 81760525, 81160249), PI foundation by Ningxia Medical University.

\section{Authors' contributions}

You Yanjie, Yu Jia, Zhang Hongfei and Yang Jingwen collected patient samples and provided technical expertise. Cao Juan and Tian Chaoyong interpreted the collected data and generated tables and figures for the data. Cao Juan wrote the manuscript. Chen Zhiqiang and Chen Jing edited the manuscript. Yang Wenjun supervised the study. All authors have read and approved the manuscript.

\section{Disclosure of interest}

The authors declare that they have no conflict of interest.

\section{Notes}

Cao Juan, Chen Zhiqiang and Chen Jing contributed equally to this work.

\section{References}

1.Yang Z, Zeng H, Xia R, Liu Q, Sun K, Zheng R, et al. Annual cost of illness of stomach and esophageal cancer patients in urban and rural areas in China: A multi-center study. Chin $\mathrm{J}$ Cancer Res. [Journal Article]. 2018 2018-08-01;30(4):439-48.

2.Yang xia, Wang Xue-wei, Li Wu-ping. Analysis on the disease distribution and change trend of malignant tumor inpatients in ningxia from 2002 to 2014. Chinese medical records, 2016. 17(01): 62-66. (In Chinese)

3.Zhang HN, Zhang ZM, Gao ZR, et al. Analysis of 10 inpatients with malignant tumors in our hospital from 1997 to 2006. China health statistics, 2008. 25(1): 46-47. (In Chinese)

4.Zeng H, Zheng R, Guo Y, Zhang S, Zou X, Wang N, et al. Cancer survival in China, 2003-2005: a population-based study. INT J CANCER. [Journal Article; Research Support, Non-U.S. Gov't]. 2015 2015-0415;136(8):1921-30.

5.Yao L, Yu F, Mao Y, Wang T, Qi Q, Ding H, et al. Gastric cancer may share genetic predisposition with esophageal squamous cell carcinoma in Chinese populations. J HUM GENET. [Journal Article]. 2018 201811-01;63(11):1159-68. 
6.Li WQ, Hu N, Wang Z, Yu K, Su H, Wang L, et al. Genetic variants in epidermal growth factor receptor pathway genes and risk of esophageal squamous cell carcinoma and gastric cancer in a Chinese population. PLOS ONE. [Journal Article; Research Support, N.I.H., Extramural; Research Support, N.I.H., Intramural; Research Support, Non-U.S. Gov't]. 2013 2013-01-20;8(7):e68999.

7.Abnet CC, Freedman ND, Hu N, Wang Z, Yu K, Shu XO, et al. A shared susceptibility locus in PLCE1 at 10q23 for gastric adenocarcinoma and esophageal squamous cell carcinoma. NAT GENET. [Journal Article; Research Support, N.I.H., Extramural; Research Support, N.I.H., Intramural]. 2010 2010-0901;42(9):764-7.

8.Wu GC, Zhang ZT. Genetic association of single nucleotide polymorphisms in P53 pathway with gastric cancer risk in a Chinese Han population. MED ONCOL. 2015;32(1):1-5.

9.Zhou Y, Li N, Zhuang W, Wu X. p53 Codon 72 polymorphism and gastric cancer risk in a Chinese Han population. Genet Test Mol Biomarkers. [Journal Article; Research Support, Non-U.S. Gov't]. 2010 2010-1201;14(6):829-33.

10.Surekha D, Sailaja K, Rao DN, Padma T, Raghunadharao D, Vishnupriya S. Codon 72 and G13964C intron 6 polymorphisms of TP53 in relation to development and progression of breast cancer in India. Asian Pac J Cancer Prev. [Journal Article; Research Support, Non-U.S. Gov't]. 2011 2011-01-20;12(8):18938.

11.Ara S, Lee PS, Hansen MF, Saya H. Codon 72 polymorphism of the TP53 gene. NUCLEIC ACIDS RES. [Journal Article]. 1990 1990-08-25;18(16):4961.

12.Souto-Garcia A, Fernandez-Somoano A, Pascual T, Alvarez-Avellon SM, Tardon A. Association of p21 Ser31 Arg and p53 Arg72Pro polymorphisms with lung cancer risk in CAPUA study. Lung Cancer (Auckl). [Journal Article]. 2012 2012-01-20;3:69-78.

13. Hebert-Magee S, Yu H, Behring M, Jadhav T, Shanmugam C, Frost A, et al. The combined survival effect of codon 72 polymorphisms and p53 somatic mutations in breast cancer depends on race and molecular subtype. PLOS ONE. [Journal Article]. 2019 2019-01-20;14(2):e211734.

14.Cheng C, Lingyan W, Yi H, Cheng Z, Huadan Y, Xuting X, et al. Association between TLR2, MTR, MTRR, XPC, TP73, TP53 genetic polymorphisms and gastric cancer: a meta-analysis. Clin Res Hepatol Gastroenterol. [Journal Article; Meta-Analysis; Research Support, Non-U.S. Gov't]. 2014 2014-0601;38(3):346-59.

15.Li M, Wang D, Wang Y, Sun G, Song W, Zhang B, et al. Association of TP53 codon 72 genotype polymorphism and environmental factors with esophageal squamous cell carcinoma in the Mongolian population of the Chinese region of Inner Mongolia. ONCOL LETT. [Journal Article]. 2017 2017-0801;14(2):1484-90. 
16. Qiao Q, Hu W. The association between TP53 Arg72Pro polymorphism and lung cancer susceptibility: evidence from 30,038 subjects. LUNG. [Journal Article; Meta-Analysis; Review]. 2013 2013-0801;191(4):369-77.

17.Jiang DK, Yao L, Wang WZ, Peng B, Ren WH, Yang XM, et al. TP53 Arg72Pro polymorphism is associated with esophageal cancer risk: a meta-analysis. World J Gastroenterol. [Journal Article; MetaAnalysis; Research Support, Non-U.S. Gov't]. 2011 2011-03-07;17(9):1227-33.

18.Toyama T, Zhang Z, Nishio M, Hamaguchi M, Kondo N, Iwase H, et al. Association of TP53 codon 72 polymorphism and the outcome of adjuvant therapy in breast cancer patients. BREAST CANCER RES. [Journal Article; Research Support, Non-U.S. Gov't]. 2007 2007-01-20;9(3):R34.

19. Huang ZH, Hua D, Li LH, Zhu JD. Prognostic role of p53 codon 72 polymorphism in gastric cancer patients treated with fluorouracil-based adjuvant chemotherapy. J Cancer Res Clin Oncol. [Journal Article]. 2008 2008-10-01;134(10):1129-34.

20.El-Deiry WS, Tokino T, Velculescu VE, Levy DB, Parsons R, Trent JM, et al. WAF1, a potential mediator of p53 tumor suppression. CELL. 1993;75(4):817-25.

21.Rati F, Mourad B, Arun F. Role of p21WAF1 in the cellular response to UV. CELL CYCLE. 2004;3(2):132-5. 22.Dong Y, Chen J, Chen Z, Tian C, Lu H, Ruan J, et al. Evaluating the Association of Eight Polymorphisms with Cancer Susceptibility in a Han Chinese Population. PLOS ONE. 2015 2015-07-15;10(7):e132797.

23.Buyru N, Tigli H, Dalay N. P53 codon 72 polymorphism in breast cancer. ONCOL REP. [Comparative Study; Journal Article; Research Support, Non-U.S. Gov't]. 2003 2003-05-01;10(3):711-4.

24.Geng P, Liao Y, Ruan Z, Liang H. Increased risk of cutaneous melanoma associated with p53 Arg72Pro polymorphism. PLOS ONE. [Journal Article; Meta-Analysis; Research Support, Non-U.S. Gov't]. 2015 201501-20;10(3):e118112.

25.Cheng $\mathrm{C}$, Lingyan W, Yi H, Cheng Z, Huadan Y, Xuting X, et al. Association between TLR2, MTR, MTRR, XPC, TP73, TP53 genetic polymorphisms and gastric cancer: a meta-analysis. Clin Res Hepatol Gastroenterol. [Journal Article; Meta-Analysis; Research Support, Non-U.S. Gov't]. 2014 2014-0601;38(3):346-59.

26.Yang W, Zhang Y, Tian X, Ning T, Ke Y. p53 Codon 72 polymorphism and the risk of esophageal squamous cell carcinoma. Mol Carcinog. [Journal Article; Research Support, Non-U.S. Gov't]. 2008 200802-01;47(2):100-4.

27.Pim D, Banks L. p53 polymorphic variants at codon 72 exert different effects on cell cycle progression. INT J CANCER. [Comparative Study; Journal Article; Research Support, Non-U.S. Gov't]. 2004 2004-0110;108(2):196-9. 
28.Schneider-Stock R, Mawrin C, Motsch C, Boltze C, Peters B, Hartig R, et al. Retention of the arginine allele in codon 72 of the 553 gene correlates with poor apoptosis in head and neck cancer. AM J PATHOL. [Journal Article; Research Support, Non-U.S. Gov't]. 2004 2004-04-01;164(4):1233-41.

29.Yagnik G, Jahangiri A, Chen R, Wagner JR, Aghi MK. Role of a p53 polymorphism in the development of nonfunctional pituitary adenomas. MOL CELL ENDOCRINOL. [Journal Article; Research Support, Non-U.S. Gov't]. 2017 2017-05-05;446:81-90.

30.Batinac T, Gruber F, Lipozencic J, Zamolo-Koncar G, Stasic A, Brajac I. Protein p53-structure, function, and possible therapeutic implications. Acta Dermatovenerol Croat. [Journal Article; Review]. 2003 2003-1201;11(4):225-30.

31. Habbous S, Pang V, Eng L, Xu W, Kurtz G, Liu FF, et al. p53 Arg72Pro polymorphism, HPV status and initiation, progression, and development of cervical cancer: a systematic review and meta-analysis. CLIN CANCER RES. [Journal Article; Meta-Analysis; Review; Systematic Review]. 2012 2012-12-01;18(23):640715.

32.Storey A, Thomas M, Kalita A, Harwood C, Gardiol D, Mantovani F, et al. Role of a p53 polymorphism in the development of human papillomavirus-associated cancer. NATURE. [Journal Article; Research Support, Non-U.S. Gov't]. 1998 1998-05-21;393(6682):229-34.

33.Thomas M, Kalita A, Labrecque S, Pim D, Banks L, Matlashewski G. Two polymorphic variants of wildtype p53 differ biochemically and biologically. MOL CELL BIOL. [Comparative Study; Journal Article; Research Support, Non-U.S. Gov't]. 1999 1999-02-01;19(2):1092-100.

34.Katkoori VR, Jia X, Shanmugam C, Wan W, Meleth S, Bumpers H, et al. Prognostic significance of p53 codon 72 polymorphism differs with race in colorectal adenocarcinoma. CLIN CANCER RES. [Journal Article; Research Support, N.I.H., Extramural]. 2009 2009-04-01;15(7):2406-16.

35.Peng JZ, Xue L, Liu DG, Lin YH. Association of the p53 Arg72Pro polymorphism with esophageal cancer in Chinese populations: a meta-analysis. Genetics \& Molecular Research. 2015;14(3):9024-33.

36.Shi H, Tan SJ, Zhong H, Hu W, Levine A, Xiao CJ, et al. Winter temperature and UV are tightly linked to genetic changes in the p53 tumor suppressor pathway in Eastern Asia. AM J HUM GENET. [Journal Article; Research Support, Non-U.S. Gov't]. 2009 2009-04-01;84(4):534-41.

37.Karimi P, Islami F, Anandasabapathy S, Freedman ND, Kamangar F. Gastric cancer: descriptive epidemiology, risk factors, screening, and prevention. Cancer Epidemiol Biomarkers Prev. [Journal Article; Research Support, N.I.H., Intramural; Review]. 2014 2014-05-01;23(5):700-13.

38.Agrawal N, Jiao Y, Bettegowda C, Hutfless SM, Wang Y, David S, et al. Comparative genomic analysis of esophageal adenocarcinoma and squamous cell carcinoma. CANCER DISCOV. [Comparative Study; Journal Article; Research Support, N.I.H., Extramural; Research Support, Non-U.S. Gov't]. 2012 2012-1001;2(10):899-905. 
39.Lin Y, Totsuka Y, He Y, Kikuchi S, Qiao Y, Ueda J, et al. Epidemiology of esophageal cancer in Japan and China. J EPIDEMIOL. [Comparative Study; Journal Article; Research Support, Non-U.S. Gov't; Review]. 2013 2013-01-20;23(4):233-42.

40.Tabuchi T, Ito Y, loka A, Nakayama T, Miyashiro I, Tsukuma H. Tobacco smoking and the risk of subsequent primary cancer among cancer survivors: a retrospective cohort study. ANN ONCOL. [Journal Article; Research Support, Non-U.S. Gov't]. 2013 2013-10-01;24(10):2699-704.

41.Wang Z, Peng S, Jiang N, Wang A, Liu S, Xie H, et al. Correction: Prognostic and clinicopathological value of p53 expression in renal cell carcinoma: a meta-analysis. Oncotarget. [Published Erratum]. 2018 2018-11-20;9(91):36406.

42.Li W, Luo S, Ma G, Wang L. Impact of liver kinase B1 on p53 and survivin and its correlation with prognosis in gastric cancer. Onco Targets Ther. [Journal Article]. 2019 2019-01-20;12:1439-45.

43.Katkoori VR, Manne U, Chaturvedi LS, Basson MD, Haan P, Coffey D, et al. Functional consequence of the p53 codon 72 polymorphism in colorectal cancer. Oncotarget. [Journal Article]. 2017 2017-0929;8(44):76574-86.

44. Hedayatizadeh-Omran A, Alizadeh-Navaei R, Janbabaei G, Omrani-Nava V, Hasheminasab Y, Amjadi O, et al. Association of P53 gene polymorphism with gastric cancer in Northern Iran as a high-risk region. Biomed Rep. [Journal Article]. 2018 2018-05-01;8(5):433-8.

\section{Tables}


Table 1. Logistic regression analysis of associations between the eight SNPs and GC in a Northwest Chinese population

\begin{tabular}{|c|c|c|c|c|c|c|c|c|c|c|c|}
\hline \multirow[t]{2}{*}{ Variables } & \multirow[t]{2}{*}{ Genotypes } & \multirow{2}{*}{$\begin{array}{l}\text { Case } \\
\text { n (\%) }\end{array}$} & \multirow{2}{*}{$\begin{array}{l}\text { Control } \\
\text { n (\%) }\end{array}$} & \multirow{2}{*}{$\begin{array}{l}\text { Crude } \\
\text { OR }\end{array}$} & \multicolumn{2}{|c|}{ 95\%CI } & \multirow[t]{2}{*}{$p$} & \multirow{2}{*}{$\begin{array}{l}\text { Adjusted } \\
\text { OR* }\end{array}$} & \multicolumn{2}{|c|}{$95 \% \mathrm{CI}$} & \multirow[t]{2}{*}{$p$} \\
\hline & & & & & Lower & Upper & & & Lower & Upper & \\
\hline \multirow[t]{4}{*}{$\begin{array}{c}\text { p53 } \\
\text { rs1042522 }\end{array}$} & $\mathrm{CC}$ & $\begin{array}{c}48 \\
(26.7)\end{array}$ & $\begin{array}{c}117 \\
(32.7)\end{array}$ & $\begin{array}{l}1.000 \\
\text { (ref) }\end{array}$ & & & & $\begin{array}{l}1.000 \\
\text { (ref) }\end{array}$ & & & \\
\hline & GC & $\begin{array}{c}89 \\
(49.4)\end{array}$ & $\begin{array}{c}174 \\
(48.6)\end{array}$ & 1.247 & 0.818 & 1.901 & 0.306 & 1.591 & 0.994 & 2.546 & 0.053 \\
\hline & GG & $\begin{array}{c}43 \\
(23.9)\end{array}$ & $\begin{array}{c}67 \\
(18.7)\end{array}$ & 1.564 & 0.940 & 2.604 & 0.085 & 2.064 & 1.159 & 3.675 & 0.014 \\
\hline & GC/GG & $\begin{array}{c}132 \\
(73.3)\end{array}$ & $\begin{array}{c}241 \\
(67.3)\end{array}$ & 1.335 & 0.897 & 1.986 & 0.154 & 1.810 & 1.151 & 2.847 & 0.010 \\
\hline \multirow[t]{4}{*}{$\begin{array}{c}\text { CDKN1A } \\
\text { rs2395655 }\end{array}$} & GG & $\begin{array}{c}41 \\
(22.8)\end{array}$ & $\begin{array}{c}106 \\
(29.6)\end{array}$ & $\begin{array}{l}1.000 \\
\text { (ref) }\end{array}$ & & & & $\begin{array}{l}1.000 \\
\text { (ref) }\end{array}$ & & & \\
\hline & GA & $\begin{array}{c}100 \\
(55.6)\end{array}$ & $\begin{array}{c}191 \\
(53.4)\end{array}$ & 1.354 & 0.877 & 2.089 & 0.172 & 1.154 & 0.720 & 1.850 & 0.551 \\
\hline & AA & $\begin{array}{c}39 \\
(21.7)\end{array}$ & $\begin{array}{c}61 \\
(17.0)\end{array}$ & 1.653 & 0.963 & 2.836 & 0.068 & 1.597 & 0.874 & 2.920 & 0.128 \\
\hline & GA/AA & $\begin{array}{c}139 \\
(77.3)\end{array}$ & $\begin{array}{c}252 \\
(70.4)\end{array}$ & 1.426 & 0.941 & 2.161 & 0.094 & 1.241 & 0.787 & 1.958 & 0.353 \\
\hline \multirow[t]{4}{*}{$\begin{array}{c}\text { CDKN1A } \\
\text { rs3176320 }\end{array}$} & AA & $\begin{array}{c}108 \\
(60.0)\end{array}$ & $\begin{array}{c}192 \\
(53.6)\end{array}$ & $\begin{array}{l}1.000 \\
\text { (ref) }\end{array}$ & & & & $\begin{array}{l}1.000 \\
\text { (ref) }\end{array}$ & & & \\
\hline & GA & $\begin{array}{c}62 \\
(34.4)\end{array}$ & $\begin{array}{c}153 \\
(42.7)\end{array}$ & 0.720 & 0.494 & 1.051 & 0.089 & 0.812 & 0.537 & 1.228 & 0.324 \\
\hline & GG & $\begin{array}{c}10 \\
(5.6)\end{array}$ & $\begin{array}{c}13 \\
(3.6)\end{array}$ & 1.368 & 0.580 & 3.223 & 0.474 & 0.869 & 0.313 & 2.408 & 0.787 \\
\hline & GA/GG & $\begin{array}{c}72 \\
(40.0)\end{array}$ & $\begin{array}{c}166 \\
(46.3)\end{array}$ & 0.771 & 0.536 & 1.109 & 0.161 & 0.822 & 0.551 & 1.225 & 0.335 \\
\hline \multirow[t]{4}{*}{$\begin{array}{c}\text { CDKN1A } \\
\text { rs3829963 }\end{array}$} & $\mathrm{CC}$ & $\begin{array}{c}66 \\
(36.7)\end{array}$ & $\begin{array}{c}127 \\
(35.5)\end{array}$ & $\begin{array}{l}1.000 \\
\text { (ref) }\end{array}$ & & & & $\begin{array}{l}1.000 \\
\text { (ref) }\end{array}$ & & & \\
\hline & CA & $\begin{array}{c}80 \\
(44.4)\end{array}$ & $\begin{array}{c}170 \\
(47.5)\end{array}$ & 0.906 & 0.608 & 1.349 & 0.626 & 0.971 & 0.627 & 1.503 & 0.894 \\
\hline & $\mathrm{AA}$ & $\begin{array}{c}34 \\
(18.9)\end{array}$ & $\begin{array}{c}60 \\
(16.8)\end{array}$ & 1.090 & 0.651 & 1.825 & 0.742 & 1.165 & 0.651 & 2.087 & 0.607 \\
\hline & CA/AA & $\begin{array}{c}114 \\
(63.3)\end{array}$ & $\begin{array}{c}230 \\
(64.3)\end{array}$ & 0.954 & 0.657 & 1.384 & 0.803 & 1.010 & 0.670 & 1.523 & 0.962 \\
\hline \multirow[t]{4}{*}{$\begin{array}{c}\text { CDKN1A } \\
\text { rs3829964 }\end{array}$} & $\mathrm{CC}$ & $\begin{array}{c}79 \\
(43.9)\end{array}$ & $\begin{array}{c}171 \\
(47.8)\end{array}$ & $\begin{array}{l}1.000 \\
\text { (ref) }\end{array}$ & & & & $\begin{array}{l}1.000 \\
\text { (ref) }\end{array}$ & & & \\
\hline & $\mathrm{CT}$ & $\begin{array}{c}84 \\
(46.7)\end{array}$ & $\begin{array}{c}155 \\
(43.3)\end{array}$ & 1.173 & 0.805 & 1.709 & 0.406 & 1.207 & 0.800 & 1.821 & 0.371 \\
\hline & TT & $\begin{array}{c}17 \\
(9.4)\end{array}$ & $\begin{array}{c}31 \\
(8.7)\end{array}$ & 1.187 & 0.620 & 2.271 & 0.605 & 0.948 & 0.459 & 1.957 & 0.884 \\
\hline & $\mathrm{CT} / \mathrm{TT}$ & $\begin{array}{c}101 \\
(56.1)\end{array}$ & $\begin{array}{c}186 \\
(52.0)\end{array}$ & 1.175 & 0.820 & 1.685 & 0.379 & 1.179 & 0.794 & 1.751 & 0.414 \\
\hline \multirow[t]{4}{*}{$\begin{array}{c}\text { CDKN1A } \\
\text { rs4135234 }\end{array}$} & GG & $\begin{array}{c}143 \\
(79.4)\end{array}$ & $\begin{array}{c}279 \\
(77.9)\end{array}$ & $\begin{array}{l}1.000 \\
\text { (ref) }\end{array}$ & & & & $\begin{array}{c}1.000 \\
\text { (ref) }\end{array}$ & & & \\
\hline & GA & $\begin{array}{c}36 \\
(20.0)\end{array}$ & $\begin{array}{c}74 \\
(20.7)\end{array}$ & 0.949 & 0.607 & 1.483 & 0.819 & 0.811 & 0.494 & 1.333 & 0.409 \\
\hline & AA & $\begin{array}{c}1 \\
(0.6)\end{array}$ & $4(1.1)$ & 0.488 & 0.054 & 4.405 & 0.523 & 0.723 & 0.062 & 8.459 & 0.796 \\
\hline & GA/AA & $\begin{array}{c}37 \\
(20.6)\end{array}$ & $\begin{array}{c}78 \\
(21.8)\end{array}$ & 0.925 & 0.596 & 1.437 & 0.730 & 0.806 & 0.493 & 1.316 & 0.389 \\
\hline \multirow[t]{3}{*}{$\begin{array}{l}\text { CDKN1A } \\
\text { rs762624 }\end{array}$} & $\mathrm{CC}$ & $\begin{array}{c}64 \\
(35.6)\end{array}$ & $\begin{array}{c}141 \\
(39.4)\end{array}$ & $\begin{array}{l}1.000 \\
\text { (ref) }\end{array}$ & & & & $\begin{array}{l}1.000 \\
\text { (ref) }\end{array}$ & & & \\
\hline & CA & $\begin{array}{c}85 \\
(47.2)\end{array}$ & $\begin{array}{c}155 \\
(43.3)\end{array}$ & 1.208 & 0.813 & 1.796 & 0.350 & 1.116 & 0.726 & 1.716 & 0.617 \\
\hline & AA & $\begin{array}{c}31 \\
(17.2)\end{array}$ & $\begin{array}{c}62 \\
(17.3)\end{array}$ & 1.102 & 0.653 & 1.858 & 0.717 & 0.909 & 0.503 & 1.643 & 0.752 \\
\hline
\end{tabular}




\begin{tabular}{|c|c|c|c|c|c|c|c|c|c|c|c|}
\hline & $\mathrm{CA} / \mathrm{AA}$ & $\begin{array}{c}116 \\
(64.4)\end{array}$ & $\begin{array}{c}217 \\
(60.6)\end{array}$ & 1.178 & 0.812 & 1.708 & 0.388 & 1.071 & 0.715 & 1.606 & 0.739 \\
\hline \multirow[t]{4}{*}{$\begin{array}{l}\text { CDKN1A } \\
\text { rs730506 }\end{array}$} & GG & $\begin{array}{c}138 \\
(76.7)\end{array}$ & $\begin{array}{c}261 \\
(72.9)\end{array}$ & $\begin{array}{c}1.000 \\
\text { (ref) }\end{array}$ & & & & $\begin{array}{c}1.000 \\
\text { (ref) }\end{array}$ & & & \\
\hline & GC & $\begin{array}{c}38 \\
(21.1)\end{array}$ & $\begin{array}{c}94 \\
(26.3)\end{array}$ & 0.765 & 0.498 & 1.175 & 0.221 & 0.866 & 0.542 & 1.384 & 0.548 \\
\hline & $\mathrm{CC}$ & $\begin{array}{c}4 \\
(2.2)\end{array}$ & $2(0.6)$ & 3.783 & 0.684 & 20.911 & 0.127 & 2.886 & 0.441 & 18.874 & 0.269 \\
\hline & $\mathrm{GC} / \mathrm{CC}$ & $\begin{array}{c}42 \\
(23.3)\end{array}$ & $\begin{array}{c}96 \\
(26.9)\end{array}$ & 0.827 & 0.545 & 1.256 & 0.374 & 0.919 & 0.583 & 1.448 & 0.716 \\
\hline
\end{tabular}

SNP, single-nucleotide polymorphism; OR, odds ratio; CI, confidence interval.

*Adjusted by age, gender, cigarette smoking, alcohol drinking (GC). 
Table 2. Logistic regression analysis of associations between the eight SNPs and EC in a Northwest Chinese population

\begin{tabular}{|c|c|c|c|c|c|c|c|c|c|c|c|}
\hline \multirow[t]{2}{*}{ Variables } & \multirow[t]{2}{*}{ Genotypes } & \multirow{2}{*}{$\begin{array}{l}\text { Case } \\
\text { n (\%) }\end{array}$} & \multirow{2}{*}{$\begin{array}{l}\text { Control } \\
\text { n (\%) }\end{array}$} & \multirow{2}{*}{$\begin{array}{l}\text { Crude } \\
\text { OR }\end{array}$} & \multicolumn{2}{|c|}{$95 \%$ CI } & \multirow[t]{2}{*}{$p$} & \multirow{2}{*}{$\begin{array}{c}\text { Adjusted } \\
\text { OR }^{*}\end{array}$} & \multicolumn{2}{|c|}{$95 \% \mathrm{CI}$} & \multirow[t]{2}{*}{$p$} \\
\hline & & & & & Lower & Upper & & & Lower & Upper & \\
\hline \multirow[t]{4}{*}{$\begin{array}{c}\mathrm{p} 53 \\
\text { rs1042522 }\end{array}$} & $\mathrm{CC}$ & $\begin{array}{c}25 \\
(22.1)\end{array}$ & $\begin{array}{c}117 \\
(32.7)\end{array}$ & $\begin{array}{l}1.000 \\
\text { (ref) }\end{array}$ & & & & $\begin{array}{l}1.000 \\
\text { (ref) }\end{array}$ & & & \\
\hline & GC & $\begin{array}{c}56 \\
(49.6)\end{array}$ & $\begin{array}{c}174 \\
(48.6)\end{array}$ & 1.506 & 0.890 & 2.550 & 0.127 & 1.883 & 1.052 & 3.370 & 0.033 \\
\hline & GG & $\begin{array}{c}31 \\
(27.4)\end{array}$ & $\begin{array}{c}67 \\
(18.7)\end{array}$ & 2.165 & 1.181 & 3.971 & 0.013 & 2.988 & 1.486 & 6.009 & 0.002 \\
\hline & GC/GG & $\begin{array}{c}87 \\
(77.0)\end{array}$ & $\begin{array}{c}241 \\
(67.3)\end{array}$ & 1.689 & 1.028 & 2.776 & 0.038 & 2.285 & 1.309 & 3.989 & 0.004 \\
\hline \multirow[t]{4}{*}{$\begin{array}{c}\text { CDKN1A } \\
\text { rs2395655 }\end{array}$} & GG & $\begin{array}{c}28 \\
(24.8)\end{array}$ & $\begin{array}{c}106 \\
(29.6)\end{array}$ & $\begin{array}{l}1.000 \\
\text { (ref) }\end{array}$ & & & & $\begin{array}{l}1.000 \\
\text { (ref) }\end{array}$ & & & \\
\hline & GA & $\begin{array}{c}61 \\
(54.0)\end{array}$ & $\begin{array}{c}191 \\
(53.4)\end{array}$ & 1.209 & 0.729 & 2.006 & 0.463 & 1.085 & 0.613 & 1.922 & 0.779 \\
\hline & AA & $\begin{array}{c}24 \\
(21.2)\end{array}$ & $\begin{array}{c}61 \\
(17.0)\end{array}$ & 1.489 & 0.794 & 2.796 & 0.215 & 1.567 & 0.755 & 3.249 & 0.228 \\
\hline & GA/AA & $\begin{array}{c}85 \\
(75.2)\end{array}$ & $\begin{array}{c}252 \\
(70.4)\end{array}$ & 1.277 & 0.787 & 2.071 & 0.322 & 1.174 & 0.679 & 2.030 & 0.566 \\
\hline \multirow[t]{4}{*}{$\begin{array}{c}\text { CDKN1A } \\
\text { rs3176320 }\end{array}$} & AA & $\begin{array}{c}62 \\
(54.9)\end{array}$ & $\begin{array}{c}192 \\
(53.6)\end{array}$ & $\begin{array}{l}1.000 \\
\text { (ref) }\end{array}$ & & & & $\begin{array}{l}1.000 \\
\text { (ref) }\end{array}$ & & & \\
\hline & GA & $\begin{array}{c}44 \\
(38.9)\end{array}$ & $\begin{array}{c}153 \\
(42.7)\end{array}$ & 0.891 & 0.573 & 1.384 & 0.606 & 0.986 & 0.601 & 1.618 & 0.957 \\
\hline & GG & $\begin{array}{c}6 \\
(5.3)\end{array}$ & $\begin{array}{c}13 \\
(3.6)\end{array}$ & 1.429 & 0.521 & 3.920 & 0.488 & 0.915 & 0.269 & 3.113 & 0.887 \\
\hline & GA/GG & $\begin{array}{c}50 \\
(44.2)\end{array}$ & $\begin{array}{c}166 \\
(46.3)\end{array}$ & 0.933 & 0.609 & 1.429 & 0.749 & 0.985 & 0.611 & 1.587 & 0.951 \\
\hline \multirow[t]{4}{*}{$\begin{array}{c}\text { CDKN1A } \\
\text { rs3829963 }\end{array}$} & $\mathrm{CC}$ & $\begin{array}{c}42 \\
(37.2)\end{array}$ & $\begin{array}{c}127 \\
(35.5)\end{array}$ & $\begin{array}{l}1.000 \\
\text { (ref) }\end{array}$ & & & & $\begin{array}{l}1.000 \\
\text { (ref) }\end{array}$ & & & \\
\hline & $\mathrm{CA}$ & $\begin{array}{c}50 \\
(44.2)\end{array}$ & $\begin{array}{c}170 \\
(47.5)\end{array}$ & 0.889 & 0.556 & 1.423 & 0.625 & 1.015 & 0.602 & 1.711 & 0.956 \\
\hline & $\mathrm{AA}$ & $\begin{array}{c}21 \\
(18.6)\end{array}$ & $\begin{array}{c}60 \\
(16.8)\end{array}$ & 1.058 & 0.577 & 1.942 & 0.855 & 1.143 & 0.568 & 2.303 & 0.708 \\
\hline & CA/AA & $\begin{array}{c}71 \\
(62.8)\end{array}$ & $\begin{array}{c}230 \\
(64.3)\end{array}$ & 0.933 & 0.602 & 1.448 & 0.758 & 1.047 & 0.639 & 1.713 & 0.856 \\
\hline \multirow[t]{4}{*}{$\begin{array}{c}\text { CDKN1A } \\
\text { rs3829964 }\end{array}$} & $\mathrm{CC}$ & $\begin{array}{c}53 \\
(46.9)\end{array}$ & $\begin{array}{c}171 \\
(47.8)\end{array}$ & $\begin{array}{l}1.000 \\
\text { (ref) }\end{array}$ & & & & $\begin{array}{l}1.000 \\
\text { (ref) }\end{array}$ & & & \\
\hline & $\mathrm{CT}$ & $\begin{array}{l}48 \\
(42.5)\end{array}$ & $\begin{array}{c}155 \\
(43.3)\end{array}$ & 0.999 & 0.639 & 1.562 & 0.997 & 1.052 & 0.640 & 1.730 & 0.841 \\
\hline & $\mathrm{TT}$ & $\begin{array}{c}12 \\
(10.6)\end{array}$ & $\begin{array}{c}31 \\
(8.7)\end{array}$ & 1.249 & 0.599 & 2.602 & 0.553 & 1.031 & 0.437 & 2.433 & 0.945 \\
\hline & $\mathrm{CT} / \mathrm{TT}$ & $\begin{array}{c}60 \\
(53.1)\end{array}$ & $\begin{array}{c}186 \\
(52.0)\end{array}$ & 1.041 & 0.681 & 1.590 & 0.853 & 1.056 & 0.657 & 1.696 & 0.822 \\
\hline \multirow[t]{4}{*}{$\begin{array}{c}\text { CDKN1A } \\
\text { rs4135234 }\end{array}$} & GG & $\begin{array}{c}87 \\
(77.0)\end{array}$ & $\begin{array}{c}279 \\
(77.9)\end{array}$ & $\begin{array}{l}1.000 \\
\text { (ref) }\end{array}$ & & & & $\begin{array}{c}1.000 \\
\text { (ref) }\end{array}$ & & & \\
\hline & GA & $\begin{array}{c}24 \\
(21.2)\end{array}$ & $\begin{array}{c}74 \\
(20.7)\end{array}$ & 1.040 & 0.619 & 1.749 & 0.882 & 1.121 & 0.625 & 2.014 & 0.701 \\
\hline & AA & $\begin{array}{c}0 \\
(0.0)\end{array}$ & $4(1.1)$ & 0.000 & 0.000 & - & 0.999 & 0.000 & 0.000 & - & 0.999 \\
\hline & GA/AA & $\begin{array}{c}24 \\
(21.2)\end{array}$ & $\begin{array}{c}78 \\
(21.8)\end{array}$ & 0.987 & 0.588 & 1.655 & 0.960 & 0.871 & 0.486 & 1.560 & 0.643 \\
\hline \multirow[t]{3}{*}{$\begin{array}{l}\text { CDKN1A } \\
\text { rs762624 }\end{array}$} & $\mathrm{CC}$ & $\begin{array}{c}42 \\
(37.2)\end{array}$ & $\begin{array}{c}141 \\
(39.4)\end{array}$ & $\begin{array}{l}1.000 \\
\text { (ref) }\end{array}$ & & & & $\begin{array}{l}1.000 \\
\text { (ref) }\end{array}$ & & & \\
\hline & CA & $\begin{array}{c}51 \\
(45.1)\end{array}$ & $\begin{array}{c}155 \\
(43.3)\end{array}$ & 1.105 & 0.692 & 1.763 & 0.677 & 1.104 & 0.657 & 1.855 & 0.710 \\
\hline & AA & $\begin{array}{c}20 \\
(17.7)\end{array}$ & $\begin{array}{c}62 \\
(17.3)\end{array}$ & 1.083 & 0.588 & 1.994 & 0.798 & 1.018 & 0.498 & 2.082 & 0.961 \\
\hline
\end{tabular}




\begin{tabular}{|c|c|c|c|c|c|c|c|c|c|c|c|}
\hline & $\mathrm{CA} / \mathrm{AA}$ & $\begin{array}{c}71 \\
(62.8)\end{array}$ & $\begin{array}{c}217 \\
(60.6)\end{array}$ & 1.098 & 0.710 & 1.700 & 0.673 & 1.070 & 0.657 & 1.744 & 0.786 \\
\hline \multirow[t]{4}{*}{$\begin{array}{l}\text { CDKN1A } \\
\text { rs730506 }\end{array}$} & GG & $\begin{array}{c}85 \\
(75.2)\end{array}$ & $\begin{array}{c}261 \\
(72.9)\end{array}$ & $\begin{array}{c}1.000 \\
\text { (ref) }\end{array}$ & & & & $\begin{array}{c}1.000 \\
\text { (ref) }\end{array}$ & & & \\
\hline & GC & $\begin{array}{c}23 \\
(20.4)\end{array}$ & $\begin{array}{c}94 \\
(26.3)\end{array}$ & 0.751 & 0.448 & 1.261 & 0.279 & 0.743 & 0.412 & 1.337 & 0.322 \\
\hline & CC & $\begin{array}{c}4 \\
(3.5)\end{array}$ & $2(0.6)$ & 6.141 & 1.105 & 34.122 & 0.038 & 4.268 & 0.713 & 25.542 & 0.112 \\
\hline & $\mathrm{GC} / \mathrm{CC}$ & $\begin{array}{c}27 \\
(23.9)\end{array}$ & $\begin{array}{c}96 \\
(26.9)\end{array}$ & 0.864 & 0.528 & 1.413 & 0.559 & 0.864 & 0.496 & 1.505 & 0.606 \\
\hline
\end{tabular}

SNP, single-nucleotide polymorphism; OR, odds ratio; CI, confidence interval; EC, esophageal cancer.

*Adjusted by age, gender, cigarette smoking and alcohol drinking (EC).

Table 3. Interaction between polymorphism of p53 rs1042522 gene and environmental risk factors in GC

\begin{tabular}{ccccccc}
\hline Environment Factors & Genotype & Case (n) & Control (n) & $c^{2}$ & $P$ & OR (95\%CI) \\
\hline Cigarette smoking & & & & & & \\
$(-)$ & CC & 23 & 75 & - & - & $1.000($ ref $)$ \\
$(-)$ & GC+GG & 59 & 185 & 0.019 & 0.889 & $1.095(0.608,1.972)$ \\
$(+)$ & CC & 25 & 42 & 3.697 & 0.055 & $1.613(0.569,4.577)$ \\
$(+)$ & GC+GG & 73 & 56 & 25.031 & $\mathbf{0 . 0 0 0}$ & $\mathbf{2 . 4 2 2}(\mathbf{1 . 1 4 5 , 5 . 1 2 3})$ \\
Alcohol Drinking & & & & & & \\
$(-)$ & CC & 29 & 88 & - & - & $1.000($ ref $)$ \\
$(-)$ & GC+GG & 90 & 224 & 0.871 & 0.351 & $1.232(0.731,2.074)$ \\
$(+)$ & CC & 19 & 29 & 3.961 & $\mathbf{0 . 0 4 7}$ & $\mathbf{1 . 4 3 7}(\mathbf{0 . 5 2 1 , 3 . 9 6 6 )}$ \\
$(+)$ & GC+GG & 42 & 17 & 36.071 & $\mathbf{0 . 0 0 0}$ & $\mathbf{5 . 1 5 2}(\mathbf{2 . 0 3 8 , 1 3 . 0 2 4 )}$ \\
\hline
\end{tabular}

Adjusted for age, gender, cigarette smoking and alcohol drinking.

OR, odds ratio; CI, confidence interval. 
Table 4. Interaction between polymorphism of p53 rs1042522 gene and environmental risk factors in EC

\begin{tabular}{ccccccc}
\hline Environment Factors & Genotype & Case (n) & Control (n) & $C^{2}$ & $P$ & OR (95\%CI) \\
\hline $\begin{array}{c}\text { Cigarette smoking } \\
(-)\end{array}$ & CC & 12 & 75 & - & - & $1.000($ ref) \\
\hline$(-)$ & GC+GG & 39 & 185 & 0.598 & 0.439 & $1.316(0.663,2.746)$ \\
\hline$(+)$ & CC & 12 & 42 & 1.676 & 0.104 & $1.127(0.557,2.386)$ \\
\hline$(+)$ & GC+GG & 48 & 56 & $\mathbf{2 3 . 0 2 5}$ & $\mathbf{0 . 0 0 0}$ & $\mathbf{5 . 3 1 0 ( 2 . 6 2 3 , 1 1 . 3 0 0 )}$ \\
\hline Alcohol Drinking & & & & & & \\
\hline$(-)$ & CC & 20 & 88 & - & - & $1.000($ ref) \\
\hline$(-)$ & GC+GG & 54 & 224 & 0.041 & 0.839 & $1.061(0.605,1.906)$ \\
\hline$(+)$ & CC & 5 & 29 & 0.259 & 0.611 & $0.760(0.236,2.139)$ \\
\hline$(+)$ & GC+GG & 33 & 17 & $\mathbf{3 4 . 5 6}$ & $\mathbf{0 . 0 0 0}$ & $\mathbf{8 . 3 9 5 ( 3 . 9 6 1 , 1 8 . 3 8 0 )}$ \\
\hline
\end{tabular}

Adjusted for age, gender, cigarette smoking and alcohol drinking.

OR, odds ratio; CI, confidence interval.

Table 5. Multivariate Cox regression model in GC patients

\begin{tabular}{|c|c|c|c|c|c|}
\hline \multirow[t]{2}{*}{ GC } & \multirow[t]{2}{*}{$P$} & 95\% CI & \multirow[t]{2}{*}{ GC } & \multirow[t]{2}{*}{ HR } & \multirow{2}{*}{$\frac{95 \% \text { CI }}{\text { lower upper }}$} \\
\hline & & lowerupper & & & \\
\hline$\overline{\mathrm{p} 53}$ & \multicolumn{2}{|c|}{0.5421 .5140 .2581 .886} & rs1042522 & \multicolumn{2}{|c|}{0.1313 .0880 .71513 .343} \\
\hline Smoking & \multicolumn{2}{|c|}{0.6741 .4050 .2886 .858} & Smoking & \multicolumn{2}{|c|}{0.7041 .3220 .3135 .574} \\
\hline Drinking & \multicolumn{2}{|c|}{0.4890 .5900 .1322 .632} & Drinking & \multicolumn{2}{|c|}{0.2100 .3300 .0581 .867} \\
\hline Tumor Size & \multicolumn{2}{|c|}{0.3472 .6180 .35219 .47} & Tumor Size & \multicolumn{2}{|c|}{0.3882 .8710 .26231 .448} \\
\hline Borrmann & \multicolumn{2}{|c|}{0.9121 .0550 .4122 .701} & Borrmann & \multicolumn{2}{|c|}{0.5410 .7240 .2582 .036} \\
\hline \multicolumn{3}{|c|}{ Lymphatic Metastasis 0.0801 .1960 .9791 .461} & Lymphatic Metastasis & 0.0511 .188 & 0.9991 .413 \\
\hline $\mathrm{T}$ & \multirow{2}{*}{\multicolumn{2}{|c|}{0.3061 .7410 .6025 .037}} & $\mathrm{~T}$ & \multicolumn{2}{|c|}{0.1652 .3730 .7018 .038} \\
\hline $\mathrm{N}$ & & & $\mathrm{N}$ & \multicolumn{2}{|c|}{0.4500 .6060 .1652 .223} \\
\hline
\end{tabular}

HR, hazard ratio; CI, confidence interval.

Table 6. List of Cox regression model variables in EC patients

\begin{tabular}{|c|c|c|c|c|c|}
\hline \multirow[t]{2}{*}{$\mathrm{EC}$} & \multirow[t]{2}{*}{$\mathrm{HR}$} & $95 \% \mathrm{CI}$ & \multirow[t]{2}{*}{$\mathrm{EC}$} & \multirow[t]{2}{*}{$D$} & \multirow[t]{2}{*}{$95 \% \mathrm{CI}$} \\
\hline & & lowerupper & & & \\
\hline 053 & \multicolumn{2}{|c|}{0.3071 .7450 .6005 .078} & $\overline{\text { rs104 }}$ & \multicolumn{2}{|c|}{0.5691 .2920 .5353 .117} \\
\hline Smoking & 0.1252 .60 & 0.7678 .815 & Smo & \multicolumn{2}{|c|}{0.0852 .9430 .86210 .045} \\
\hline Drinking & \multicolumn{2}{|c|}{0.7400 .8050 .2242 .893} & Drinking & \multicolumn{2}{|c|}{0.9281 .0550 .3293 .389} \\
\hline \multicolumn{2}{|c|}{ Tumor Size 0} & 0.203 & Tums & \multicolumn{2}{|c|}{$\begin{array}{lllll} & 0.5630 .786 & 0.348 & 1.777\end{array}$} \\
\hline $\mathrm{T}$ & \multicolumn{2}{|c|}{0.1670 .4640 .1561 .380} & $\mathrm{~T}$ & \multicolumn{2}{|c|}{0.6930 .8960 .5211 .543} \\
\hline $\mathrm{N}$ & \multicolumn{2}{|c|}{$\mathbf{0 . 0 3 6 2 . 2 2 1 1 . 0 5 3 4 . 6 8 7}$} & $\mathrm{N}$ & \multicolumn{2}{|c|}{0.0602 .1060 .9694 .574} \\
\hline
\end{tabular}

HR, hazard ratio; CI, confidence interval. 


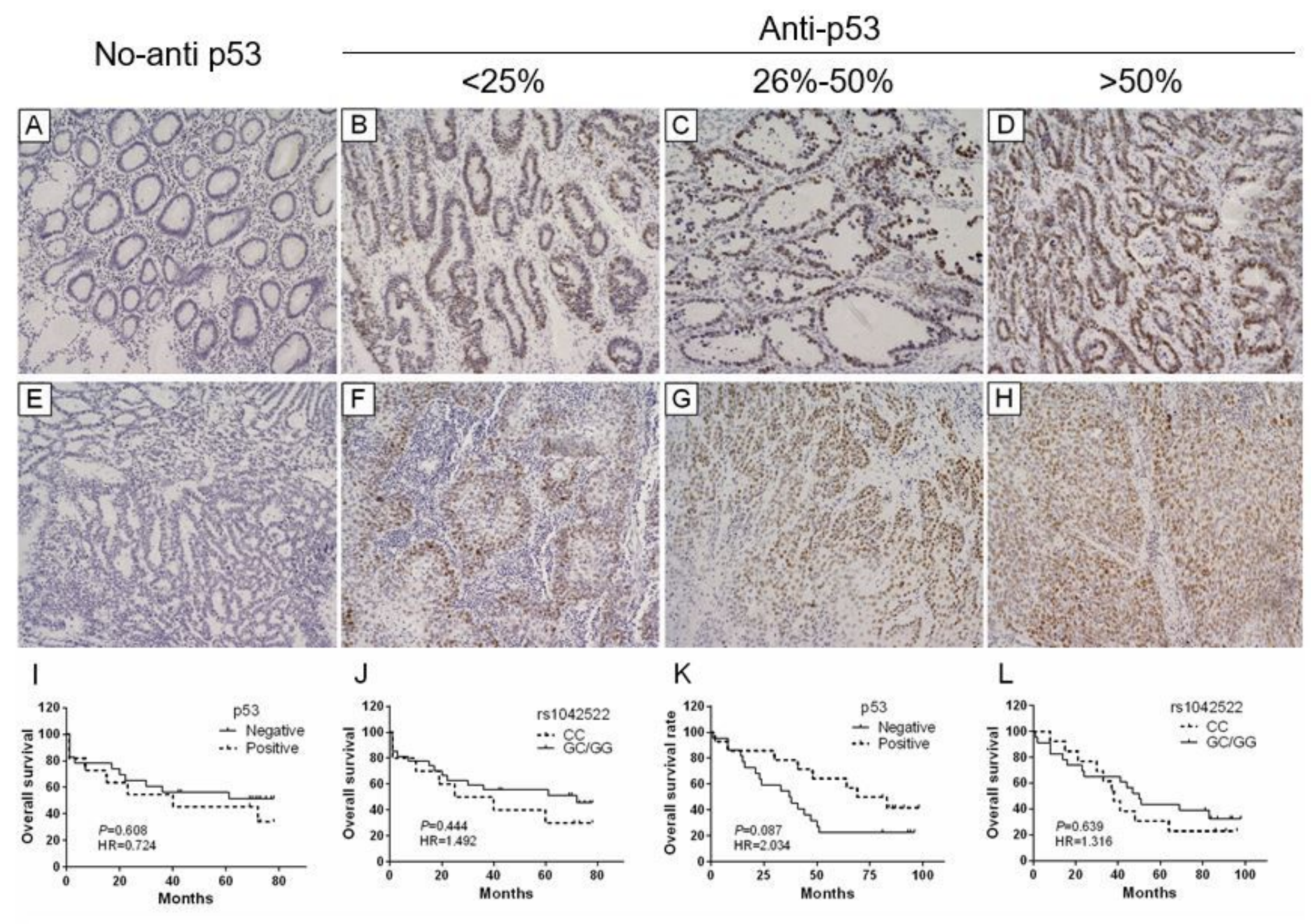

\section{Figure 1}

Immunohistochemistry staining of the P53 protein in GC and EC tissues and the relationship between p53 or rs1042522 and overall survival in GC and EC patients. (A, E) No-anti p53, negative control with primary antibody replaced by PBS. (B-D, F-H) Anti-p53, the brown signals represent positive staining for P53 protein and the staining was scored on a scale as indicated in the Materials and methods. Positive cases were defined as those with over $10 \%$ of examined cells stained. Magnification, $\times 200$. $(\mathrm{I}, \mathrm{J})$ The survival curves of GC patients in different P53 expression levels and rs1042522. $(K, L)$ The survival curves of EC patients in different P53 expression levels and rs1042522.

\section{Supplementary Files}

This is a list of supplementary files associated with this preprint. Click to download.

- SupplementaryCJJune19.doc 